E-ISSN : 2655-7347

\title{
TANGGUNG JAWAB PPAT DALAM HAL PEMBUATAN AKTA JUAL- BELI TANPA SEPENGETAHUAN AHLI WARIS
}

\author{
Jodhantara Aulliandika \\ (Mahasiswa Fakultas Hukum Untar) \\ Email: jodhantaraaulliandika@yahoo.com
}

\section{Dr. Gunawan Djajaputra, S.H., S.S., C.N., M.H. \\ (Corresponding Author)}

(Dosen Tetap Universitas Tarumanagara, Mengajar Hukum Perdata di Universitas Tarumanagara, Meraih Gelar Sarjana Hukum, Magister Hukum dan Doktor di Universitas Indonesia)

(Email:gunjapp62@yahoo.com)

\begin{abstract}
Land Deed Makers / PPAT Officers are officials who have the authority to make authentic deeds related to legal actions such as making land sale and purchase deeds. However, in practice, PPAT is often used as a part of the Defendant because of inaccuracy or inadvertence in making the sale and purchase deeds to the detriment of the heirs of the landowner. So the problem arises how the accountability of PPAT in terms of making Deed of Sale and Purchase without the knowledge of the Heirs of the Land? The method used is a normative legal research method. Based on PPAT Cikampek analysis results in decision number 12 / PDT.G / 2017 / PN.KWG declared to have committed acts against the law in carrying out their duties violating the precautionary principle of making Deed of Sale without the presence of Seller / heir so that, PPAT is dropped Article Acts against the law but without being held accountable, it should be in accordance with the provisions of Article 1365 of the Indonesian Criminal Code, a person who commits an act against the law is obliged to provide compensation, but in this decision the judge does not decide on the PPAT to be responsible but impose the article on illegal acts against PPAT with the regions Cikampek sub-district, Karawang Regency.
\end{abstract}

Keywords: PPAT responsibility, deed of sale and purchase, without the knowledge of, heirs

\section{PENDAHULUAN}

\section{A. Latar Belakang}

Tanah dan seluruh isinya adalah anugerah yang telah Tuhan berikan kepada umat manusia untuk dimanfaatkan sebaik-baiknya agar tercipta kesejahteraan kelangsungan hidup manusia di bumi. Bagi sebagian masyarakat Indonesia, menggantugkan hidupnya dari tanah melalui usaha pertanian, peternakan, dan lainlain. ${ }^{1}$ Oleh karena itu, memiliki tanah adalah dambaan dan harapan bagi setiap orang, karena tanah selain memiliki nilai historis bagi pemiliknya, tanah juga

\footnotetext{
${ }^{1}$ Sri Hajati, dkk, Buku Ajar Politik Hukum Pertanahan, Cetakan Pertama, (Surabaya: Airlangga University Press, 2017), hal.1.
} 
memiliki nilai ekonomis yang ke depan prospeknya cukup menjanjikan bagi kelangsungan hidup seseorang.

Mengingat keberadaan tanah merupakan faktor yang sangat penting bagi kehidupan masyarakat, maka permasalahan pertanahan menjadi perkara yang sangat sensitif dan cukup komplek jika sengketa tanah itu terjadi apalagi pihakpihak yang bersengketa tidak memiliki bukti kepemilikan. Untuk menghindari konflik yang berkaitan dengan masalah pertanahan, maka pemilik tanah harus memiliki sertipikat atau girik sebagai bukti kepemilikan. ${ }^{2}$ Sertipikat tanah merupakan bukti otentik pemegang hak yang didasarkan pada data fisik dan data yuridis yang telah didaftarkan dalam buku tanah, ${ }^{3}$ yang dikeluarkan oleh pejabat Badan Pertanahan Nasional (BPN) dengan tetap merujuk pada tempat dimana akta itu dibuat. ${ }^{4}$

Pada umumnya seseorang menguasai atau memiliki tanah diperoleh melalui hibah, waris, jual-beli dan tukar menukar. Jual-beli merupakan salah satu budaya yang telah dipraktekan sejak dahulu kala yang kini telah menjadi kebiasaan masyarakat dalam pemenuhan kebutuhan hidupnya. Melalui proses jual-beli, barang yang diinginkan dapat dinikmati dan digunakan sesuai dengan keperluan dan kepentingannya.

Banyak dijumpai di masyarakat untuk memiliki tanah diperoleh melalui transaksi jual-beli, dan untuk memperkuat keabsahan jual-beli dibuatlah suratsurat dalam bentuk akta jual-beli (AJB) dihadapan Pejabat Pembuat Akta Tanah (PPAT) ${ }^{5}$ Apabila dalam transaksi jual-beli di daerah tersebut belum ada PPAT, undang-undang telah memberi kewenangan kepada Camat yang dalam jabatan atau kapasitasnya dipersamakan sebagai PPAT sementara. ${ }^{6}$ Keberadaan PPAT/Camat di wilayah-wilayah tertentu yang belum ada PPAT sangat dibutuhkan masyarakat dalam pembuatan surat-surat tanah/rumah menjadi penting

\footnotetext{
${ }^{2}$ Peraturan Pemerintah Nomor 24 Tahun 1997 tentang Pendaftaran Tanah, Pasal 4 ayat (1) jo. Pasal 3 huruf a.

3 Jimmy Joses Sembiring, Panduan Mengurus Sertipikat Tanah, Cetakan Pertama, (Jakarta: Visimedia, 2010), hal.43.

${ }^{4}$ Kian Goenawan, Panduan Mengurus Sertipikat Tanah dan Property, Cetakan ke-1, (Yogyakarta: Bes Publisher, 2009), hal. 9.

${ }^{5}$ Urip Santoso, Perolehan Hak Atas Tanah, Cetakan Pertama, (Jakarta: Kencana,2015), hal.105.

6 Eko Yulian Isnur, Tata Cara Mengurus Surat-Surat Rumah dan Tanah, Cetakan Ketiga, (Yogyakarta: Pustaka Yustisia, 2009), hal.70
} 
karena untuk melindungi hak serta memberikan jaminan kepastian hukum atas kepemilikannya. $^{7}$

Jual-beli secara umum diartikan sebagai perjanjian timbal balik antara penjual dan pembeli sama-sama memiliki kesepakatan atas objek barang yang diperjanjikan. Pembeli memiliki kewajiban untuk menyerahkan objek barang, sedangkan penjual menyerahkan sejumlah uang untuk membayar objek barang. Ketentuan tentang jual-beli tetap merujuk pada KUHPer Pasal 1457 dijelaskan bahwa perjanjian jual-beli adalah suatu perjanjian timbal balik, di mana pihak yang satu atau penjual berjanji untuk menyerahkan suatu objek barang yang diperjanjikan kepada pihak lain dalam hal ini pembeli dengan syarat dilakukan pembayaran sesuai yang telah diperjanjikan. Ketentuan lain yang masih ada kaitannya dengan jual-beli yaitu Pasal 1458 KUHPer, yang pada intinya menekankan telah terjadi transaksi jual-beli dan sah secara hukum seketika apabila telah terjadi kesepakatan kedua belah pihak meskipun pembayaran belum lunas. Artinya, bahwa jual-beli tersebut dibenarkan asalkan kedua belah pihak menyepakati yang proses pembayarannya menjadi kesepakatan kedua belah apakah melalui proses kredit atau membayar kekurangannya secara tempo dengan waktu yang ditentukan.

Implikasi dari adanya perjanjian jual-beli adalah beralihnya hak kepemilikan dan penguasaan. Begitu pula dalam perjanjian jual-beli tanah, maka menurut ketentuan Peraturan Pemerintah Nomor 24 Tahun 2007, perjanjian yang berhubungan dengan masalah perpindahan hak atas tanah termasuk di dalamnya jual-beli tanah, harus turut melibatkan pihak PPAT. Oleh karena itu, dalam pelaksanaan jual-beli, kedua belah pihak penjual dan pembeli sangat diupayakan datang bersama-sama dan menghadap ke kantor PPAT atau Kantor Camat setempat untuk kemudian dibuat akta jual-beli. ${ }^{8}$

Menurut Sri Harjati dkk, dalam jual-beli tanah ada ketentuan yang harus dipenuhi oleh para pihak yaitu syarat materil maupun formil. Pemenuhan syarat materil mengharuskan penjual maupun pembeli sebagai pihak yang benar-benar berhak, berwenang dan boleh melakukan jual-beli tanah dan hanya pemegang hak

\footnotetext{
${ }^{7}$ Ibid., hal.27.

${ }^{8}$ Ibid, hal. 70.
} 
tanah sajalah yang dapat melakukan jual-beli. Sedangkan syarat formil, kedua belah pihak yang melakukan perjanjian jual-beli tanah harus menghadap ke PPAT untuk dibuatkan akta sebagai bukti telah terjadinya peristiwa hukum jual beli tanah, apabila tidak dibuatkan akta dihadapan PPAT, maka akan menglamai kesulitan dalam proses pendaftaran tanah selanjutnya. ${ }^{9}$ Tanpa adanya bukti akta dari PPAT, jual-beli tidak dapat di daftar karena akta PPAT merupakan salah satu syarat-mutlak untuk pendaftaran peralihan tersebut. ${ }^{10}$ Selain itu, dalam perjanjian jual-beli tanah juga harus terpenuhinya syarat sah perjanjian sesuai Pasal 1320 KUHPer yaitu adanya kesepakatan, kecakapan syarat objek tertentu dan kausa yang diperkenankan. ${ }^{11}$

Persyaratan tersebut secara hukum memang harus terpenuhi agar di kemudian hari transaksi jual-beli tanah tidak menemui masalah di masa mendatang, karena apabila terjadi masalah, maka pihak yang merasa dirugikan dapat melakukan proses hukum penuntutan ke pengadilan. Kondisi ini seperti terjadi dalam kasus perkara Putusan No. 12/PDT.G/2017/PN.KWG, karena adanya ahli waris sebagai pemegang hak atas tanah tidak merasa melakukan transaksi jualbeli tanah, akan tetapi tanah telah beralih ke pihak lain melalui proses jual-beli yang penuh dengan rekayasa karena pihak penjual statusnya sudah meninggal dunia, namun anehnya seolah-olah telah melakukan transaksi jual-beli yang secara logika dan nalar sehat tidak dibenarkan dengan alasan apapun.

Dalam kasus ini Penggugat A.Djumena melawan Tergugat- I (Satu), Arif Bambang Sutyadi dan Tergugat-II PPAT H.M Atori Hasanudin. Pada tahun 1973 nenek Penggugat bernama Usni semasa hidupnya memiliki sebidang tanah seluas 4,995 Ha (empat koma sembilan ratus sembilan puluh lima hektar) berdasarkan Kikitir (C) No.1883, Persil No.181, Blok D.IV Desa Dawuan Barat, Kecamatan Cikampek Kabupaten Karawang yang di wariskan kepada ayah penggugat yang bernama Hadiwinata yang sudah meninggal.

\footnotetext{
${ }^{9}$ Sri Hajati, dkk, Op.Cit., hal.202.

${ }^{10}$ Maria S.W. Soemardjono, Kebijakan Pertanahan, antara Peraturan dan Implementasi, Cetakan Ketiga, Edisi Revisi, (Jakarta: Kompas Gramedia, 2005), hal. 139.

${ }^{11}$ Agus Yudha Hernoko, Hukum Perjanjian Asas Proporsisionalitas dalam Kontrak Komersial, Edisi Pertama, Cetakan Keempat, (Jakarta: Kencana, 2014), hal.160.
} 
Sampai tahun 2015 tanah tersebut masih kosong dan tidak digarap. selanjutnya pada awal tahun 2016 Penggugat bermaksud untuk memanfaatkan sebidang tanah tersebut namun muncul pihak yang mengaku sudah membeli tanah milik almarhumah Usni yaitu Arif Bambang Sutyadi (Tergugat-I). Saat itu Tergugat I memperlihatkan Akta Jual-beli No.914/Kec-Ckp/VII/1990 tertanggal 4 Juli 1990 yang dibuat dihadapan/oleh H.M.Atori Hasanudin, BA, PPAT/Camat dengan daerah kerja Kecamatan Cikampek Kabupaten Karawang (Tergugat-I).

Penggugat melakukan pengecekan ke Kecamatan Cikampek berkaitan dengan Akta Jual-beli dimaksud, dan ternyata memang ada Akta Jual-beli tersebut selanjutnya Penggugat meminta salinan Akta Jual-beli No.914/Kec-Ckp/VII/1990 tertanggal 4 Juli 1990. Namun, setelah Penggugat mencermati Akta Jual-beli No.914/Kec-Ckp/VII/1990 tertanggal 4 Juli 1990 ternyata didapati ketidakbenaran dalam akta yang di berikan. Bahwa ketidakbenaran tersebut adalah Akta Jual-beli No.914/Kec-Ckp/VII/1990 tertanggal 4 Juli 1990 padahal Usni (nenek Penggugat) meninggal dunia pada tanggal 15 Desember 1989 (Usni meninggal enam bulan lebih dulu dari terbitnya Akta Jual-beli), sehingga Penggugat menganggap Akta Jual-beli No.914/KecCkp/VII/1990 tertanggal 4 Juli 1990 mengandung cacat yuridis karena berisi kebohongan karena kebohongan yang ada dalam terbitnya Akta Jual-beli No.914/KecCkp/VII/1990 tertanggal 4 Juli 1990, maka perbuatan Tergugat I dan Tergugat II patut dikategorikan sebagai perbuatan melawan hokum yang telah merugikan Penggugat yang merupakan ahli waris yang berhak atas warisan neneknya melalui orang tua pengguat berupa sebidang tanah seluas 4,995 Ha (empat koma sembilan ratus sembilan puluh lima hektar) berdasarkan Kikitir (C) No. 181, Blok D.IV, Desa Dawuan Barat, Kecamatan Cikampek, Kabupaten Karawang.

Dalam Point ini Tergugat-I telah melakukan perbuatan melawan hukum karena telah merekayasa terbitnya Akta Jual-beli No.914/Kec-Ckp/VII/1990 tertanggal 4 Juli 1990, padahal orang yang tertera di Akta dimaksud sebagai penjualnya telah meninggal dunia sejak tanggal 15 Desember 1989 (enam bulan sebelumnya).

Tergugat-II pun telah melakukan tindakan melawan hukum karena dalam melaksanakan tugas profesinya sebagai PPAT dengan wilayah kerja Kecamatan 
Volume 2 Nomor 2, Desember 2019

E-ISSN : 2655-7347

Cikampek dinilai telah melanggar prinsip kehati-hatian yaitu membuat Akta Jual-

Beli tanpa kehadiran pihak penjual mupun pembeli. Oleh karena itu penelitian ini akan diuraikan lebih lanjut perihal masalah pertanggungjawaban pihak PPAT yang telah membuat akta jual-beli tanah yang tanpa sepengetahuan ahli waris.

\section{B. Permasalahan}

Berdasarkan latar belakang di atas yang telah di uraikan oleh penulis maka dirumskanlah permasalahan yaitu:Bagaimana pertanggung jawaban PPAT dalam hal membuat Akta Jual-Beli tanpa sepengetahuan Ahli Waris Tanah?

\section{Metode Penelitian}

Dalam penelitian ini, metode yang digunakan yaitu metode penelitian hukum normatif dengan data sekunder yang diperoleh melalui pengumpulan dan penelaahan berdasarkan studi kepustakaan (library research). Penelitian ini menggunakan dua pendekatan yaitu pendekatan kasus yang diperoleh dari data lapangan dalam perkara sengketa jual-beli tanah yang telah diputus oleh pengadilan melalui Putusan No. 12/PDT.G/2017/PN.KWG, sedangkan yang kedua yaitu pendekatan undang-undang yang menelaah beberapa ketentuan perundang-undangan berhubungan dengan masalah yang diteliti.

\section{ANALISIS}

\section{A. Uraian Kasus}

Peristiwa perselisihan dalam jual-beli tanah seringkali mengemuka karena berbagai faktor. Salah satu di antaranya yaitu karena salah satu pihak merasa tidak pernah menjual atau mengalihkan tanah hak miliknya ke orang lain, namun ada klaim dari pihak lain yang merasa telah membeli atas tanah yang disengketakan tersebut. Seperti halnya terjadi dalam perkara Putusan Nomor 12/Pdt/G/2017/ PN.Kwg yang juga telah dikuatkan oleh Putusan Banding pada Pengadilan Tinggi Bandung Nomor: 530/PDT/2017/PT.BDG.

Para pihak yang bersengketa dalam perkara ini yaitu A. Djumena selaku Penggugat. A. Djumena merupakan cucu dari nenek Usni selaku pemilik sebidang tanah seluas 4,995 Ha (empat koma sembilan ratus sembilan puluh lima hektar) 
berdasarkan Kikitir No.1883, Persil No. 181 beralamat di Jl. Blok D.IV Desa Dawuan Barat, Cikampek Kabupaten Karawang.

Arif Bambang Sutyadi selaku Tergugat I yang merupakan pihak yang mengklaim telah membeli tanah tersebut pada tanggal sesuai dengan akta jual-beli. Selanjutnya pihak camat/PPAT Kecamatan Cikampek yang dijadikan sebagai Tergugat II karena perannya telah membuat Akta Jual-beli No.914/KecCkp/VII/1990 tertanggal 4 Juli 1990 tanpa sepengetahuan ahli waris.

Perselisihan muncul pada awal 2016 ketika Penggugat hendak memanfaatkan objek tanah milik nenek Usni yang pada tahun 2015 masih kosong tidak digarap. Penggugat merasa kaget karena pada awal tahun 2016 pada saat mendatangi tanah tersebut ada pihak yang mengklaim telah membeli dari almarhum Usni yaitu Tergugat I yang kemudian diperlihatkan bukti jual-beli yang telah ditandatangai oleh Tergugat II dalam bentuk Akta Jual-beli No.914/KecCkp/VII/1990 tertanggal 4 Juli 1990.

Untuk memastikan keabsahan akta jual-beli tersebut, Penggugat melakukan pengecekan ke Kecamatan Cikampek dan setelah dilakukuan pengecekan ternyata benar adanya transaksi jual-beli tanah sesuai dengan yang tertulis dalam akta tersebut. Dikarenakan masih kurang yakin atas akta jual-beli tersebut, maka Penggugat kemudian meneliti kembali dengan cermat antara tanggal jual-beli dengan kematian neneknya. Setelah dicermati secara mendalam, bahwa ditemukan adanya ketidakbenaran yang cukup janggal dalam penulisan waktu jual-beli karena nenek Usni telah meninggal dunia pada 15 Desember 1989, sedangkan akta jual-beli tertulis tanggal 4 Juli 1990. Dengan melihat fakta tersebut, jelas terjadi ketidaksesuaian karena salah satu pihak dalam akta tersebut sudah meninggal 6 (enam) bulan yang lalu yang secara logika tidak mungkin melakukan transaksi jual-beli tanah untuk tanggal 4 Juli 1990 sehingga akta jual-beli tersebut menurut pandangan Penggugat mengandung cacat yuridis karena berisi kebohongan.

Terbitnya Akta Jual-beli No.914/Kec-Ckp/VII/1990 tertanggal 4 Juli 1990 yang tidak sesuai dan berisi kebohongan telah meyakinkan Penggugat bahwa transaksi jual-beli tanah tersebut sebagai.perbuatan melawan hukum yang telah merugikan A.Djumena selaku Penggugat yang merupakan salah satu ahli waris 
yang berhak atas warisan dari orang tua berupa sebidang tanah yang menjadi objek sengketa. Dengan demikian, maka dapat dikatakan Penggugat I telah melakukan perbuatan melawan hukum karena telah merekayasa terbitnya Akta Jual.Beli No.914/Kec-Ckp/VII/1990 tertanggal 4 Juli 1990, padahal orang yang tercantum dalam akta sebagai penjuual telah meninggal dunia tanggal 15 Desember 1989 yang tidak mungkin melakukan transaksi jual-beli untuk tanggal 4 Juli 1990.

Demikian pula dengan Tergugat-II yang telah mengeluarkan dan mengsahkan Akta Jual Beli No.914/Kec-Ckp/VII/1990 tertanggal 4 Juli 1990 telah turut melakukuan perilaku yang telah melawan hukum dikarena didalam menjalankan tugasnya sebagai PPAT dengan wilayah kerja Kecamatan Cikampek dinilai telah melanggar prinsip kehati-hatian dan tidak cermat dan teliti karena membuat akta jual beli tanpa kehadiran penjual dan pembeli. Tergugat I maupun Tergugat II dapat dikatakan sebagai pihak yang telah melakukan perilaku menyimpang dari hukum yang berlaku.

Berdasarkan dalil yang telah diajukan, Penggugat memohon kepada Ketua Majelis Hakim untuk menerima dan mengabulkan seluruh gugatan dan menyatakan sah dan berharga seluruh bukti-bukti yang diajukan di muka persidangan. Menyatakan Tergugat-I sebagai pihak yang telah melakukan perbuatan melawan hukum karena telah merekayasa terbitnya akta jual beli yang penuh dengan kebohongan dan untuk Tergugat-II telah melanggar prinsip ketidak cermatan dan ketidakpenuh hati-hatian karena membuat akta jual-beli tanpa menghadirkan penjual dan pembeli sebagai perbuatan melawan hukum. Begitupula dengan terbitnya Akta Jual Beli No.914/Kec-Ckp/VII/1990 tertanggal 4 Juli 1990 yang mengandung cacat yuridis sehingga harus dinyatakan batal demi hukum dan tidak memiliki kekuatan hukum mengikat serta para tergugat harus tunduk dan patuh terhadap isi putusan pengadilan dan dibebankan membayar biaya yang timbul dalam proses perkara di pengadilan.

\section{Eksepsi Tergugat}

Menjawab tuntutan Penggugat, Tergugat-II mengajukan eksepsi atau jawaban terkait permasalahan tersebut yang pada pokoknya Tergugat-II mempermasalahkan kewenangan absolut perihal gugatan yang seharusnya 
didaftarkan ke PTUN, dengan alasan karena setelah dicermati secara seksama, yang menjadi dasar dalam gugatan adalah Akta Jual-Beli No.914/KecCkp/VII/1990 tertanggal 4 Juli 1990. Selain itu, Penggugat juga dengan tegas dan jelas baik dalam posita maupun dalam petitum menuntut agar Pengadilan Negeri Karawang membatalkan Akta Jual-Beli No.914/Kec-Ckp/VII/1990 tertanggal 4 Juli 1990 yang telah dikeluarkan oleh Camat Cikampek selaku PPAT yang merupakan pejabat PTUN, dengan demikian akta jual-beli tersebut merupakan Keputusan TUN hal ini sesuai dengan ketentuan Pasal 1 angka 9 UU No.51/2009 tentang PTUN yang menyatakan bahwa Keputusan Tata Usaha Negara adalah suatu penetapan tertulis yang dikeluarkan oleh Badan atau Pejabat TUN yang berlaku bersifat konkrit, individual dan final yang menimbulkan akibat hukum bagi orang atau badan hukum perdata. Oleh dikarenakan hal tersebut, AJB No.914/KecCkp/VII/1990 tertanggal 4 Juli 1990, merupakan suatu Keputusan Tata Usaha Negara, maka Peradilan Umum (Pengadilan Negeri) tidak memiliki kewenangan untuk mengadilinya dan yang berwenang untuk memeriks dan mengadilinya adalah Pengadilan Tata Usaha Negara.

Dengan demikian, Tergugat-II menyatakan berdasarkan hal-hal tersebut di atas, maka telah jelas dan terang bahwa gugatan Penggugat yang memohon pembatalan Akta Jual-Beli No.914/Kec-Ckp/VII/1990 tertanggal 4 Juli 1990 adalah merupakan kewenangan Peradilan Tinggi Tata Usaha Negara, sehingga gugatan Penggugat harus dinyatakan ditolak.

Ekspeksi Tergugat II menilai gugatan Penggugat kabur atau tidak jelas (obscuur libel), karena Penggugat tidka jelas menyebutkan objek sengketa dalam perkara ini, apakah yang menjadi objek sengketa dalam perkara ini adalah tanah seluas 4,995 (empat koma sembilan ratus sembilan puluh lima hektar) berdasarkan Kikitir No.1883, Persil No. 181 beralamat di Jl. Blok D.IV Desa Dawuan Barat, Cikampek Kabupaten Karawang dengan batas-batas meliputi sebelah utara berpatasan dengan Darat Linawati, sebelah timur berbatasan dengan jalan desa, sebelah selatan berbatasan dengan jalan tol Jakarta-Cikampek dan sebelah barat berbatasan dengan Darat milik H. Hasan Basri; atau Akta Jual-beli No.914/KecCkp/VII/1990 tertanggal 4 Juli 1990 karena tidak ada kejelasan mengenai objek 
sengketa dalam perkara ini, maka gugatan Pengguat menjadi kabur sehingga harus ditolak atau setidak-tidaknya dinyatakan tidak dapat diterima.

Berdasarkan eksepsi tersebut, maka Tergugat II memohon kepada Majelis Hakim Pengadilan Negeri Karawang yang memeriksa dan mengadili perkara ini untuk memutus perkara dengan amar putusan mengabulkan ekspesi Tergugat II untuk seluruhnya, dan dalam pokok perkara menolak gugatan Penggugat untuk seluruhnya atau setidak-tidaknya menyatakan gugatan Penggugat tidak dapat diterima. (niet onvabkelijke verklaard) atau menghukum Penggugat untuk membayar seluruh biaya perkara.

\section{Pertimbangan Hakim Pengadilan Negeri Karawang}

Dalam pertimbangannya, hakim Pengadilan Negeri Karawang yang memeriksa dan mengadili perkara ini terdapat pertimbangan-pertimbangan dari kedua belah pihak yang bsesengketa. Majelis hakim juga telah memeriksa objek tanah yang menjadi sengketa dengan disaksikan anak dari penggugat bersama kuasa hukumnya, dan dihadiri oleh Kepala Desa setempat yang telah terlebih dahulu secara resmi diketahui oleh Pengadilan Negari Karawang melalui surat resmi tertanggal 26 April 2017 Nomor W11.U10/568/HT.04.10/ IV/2017. Tanah yang telah diperiksa tersebut adalah tanah sebagaimana objek dalam Akta Jual-beli No.914/Kec-Ckp/VII/1990 tertanggal 4 Juli 1990, dengan gambar situasi yang dijadikan sebagai bukti di pengadilan yang merupakan bagian yang tidak terpisahkan dengan putusan ini.

Dalam pertimbangan.eksepsi Tergugat, hakim telah mempertimbangkan dalam putusan sela tanggal 3 Mei 2017 yang amarnya.menolak.eksepsi Tergugat II mengenai kewenangan mengadilan (kompetensi absolut) dan memerintahkan kedua belah.pihak.untuk.melanjutkan persidangan serta menangguhkan biaya hingga adanya putusan akhir. Perihal eksepsi gugatan kabur, eksepsi Tergugat ditolak karena objek tanah tersebut telah jelas yang menjadi objek.sengketa.dalam perkara ini yaitu Akta.Jual.Beli No.914/Kec-Ckp/VII/1990 tertanggal 4 Juli 1990, 
sehingga diketahui bahwa pertimbangan hakim dalam perkara ini menolak keseluruhan eksepsi tergugat tersebut.

Pertimbangan hakim dalam pokok perkara ini yaitu perihal gugatan Penggugat yang pada pokoknya mengenai pembatalan Akta Jual-beli No.914/KecCkp/VII/1990 tertanggal 4 Juli 1990 antara Nenek Husni dan Tergugat.I.yang dibuat.di hadapan.Tergugat.II yaitu Camat/PPAT Kecamatan Cikampek, Kabupaten Karawang yang pada saat itu dijabat oleh H.M. Atori Hasanudin, BA. Oleh karena itu, hakim mempertimbangkan bahwa diakui atau setidak-tidaknya tidak disangkal, maka menurut hukum harus dianggap terbukti hal-hal sebagai berikut:

1. Bahwa akta jual-beli sebidang tanah seluas $4,995 \mathrm{Ha}$ (empat ribu sembilan ratus sembilan puluh lima hektar) berdasarkan Kikitir (C) No.1883, Persil No.181, Blok D.IV Desa Dawuan Barat, Kecamatan Cikampek Kabupaten Karawang, tertanggal 4 Juli 1990.

2. Bahwa akta jual-beli tersebut antara Usni selaku penjual dengan arif Bambang Sutyadi (Tergugat-I) yang dibuat dihadapan Camat/PPAT Kecamatan Cikampek (Tergugat-II).

Menjadi persengketaan kedua belah pihak adalah apakah perbuatan Tergugat-I dan Tergugat-II sebagai tindakan perbuatan.melawan.hukum dalam penerbitan Akta Jual-beli No.914/Kec-Ckp/VII/1990 tertanggal 4 Juli 1990. Untuk menjawabnya, majelis hakim akan mempertimbangkan mengenai legal standing dari Penggugat dalam mengajukan gugatan ini.

Berdasarkan bukti yang ada berupa KTP atas nama Penggugat yang menerangkan bahwa Penggugat adalah Penduduk Karawang yang dibuktikan dengan adanya hubungan keluarga menerangkan bahwa kakek Penggugat bernama Winata telah.meninggal.dunia dan pernah menikah.dengan.seorang.perempuan bernama Usni dimana dari pernikahan Winata dan Usni dikaruniai 2 (dua) orang anak yaitu almarhumah $\mathrm{Hj}$. Marni dan Amlarhum Hadiwinata (Ayah Penggugat) dan ayah Penggugat memiliki 6 (enam) anak yang salah satunya yaitu Penggugat anak ke-5 dari Almarhum Hadiwinata. Keterangan tersebut juga diperkuat oleh saksi-saksi bahwa Usni sebagai pemilik tanah dimaksud dalam Akta Jual-beli No.914/Kec-Ckp/VII/1990 mempunyai anak bernama Hadiwinata yang tidak lain 
merupakan ayah dari Penggugat. Dengan demikian, menurut Majelis Hakim, Penggugat mempunyai kapasitas (legalstanding in judicio) untuk menjadi pihak Penggugat dalam perkara ini.

Majelis hakim juga mempertimbangkan apakah Tergugat.I dan Tergugat.II telah meakukan perbuatan melawan hukum dalam penerbitan AJB No.914/KecCkp/VII/1990 terssebut, maka berdasarkan Pasal 163 HIR/283 RBG, Pengguat berkewajiban untuk membuktikan hal tersebut di atas. Untuk menguatkan alasan nya, Penggugat telah mengajukan seluruh bukti-bukti dan keterangan para saksisaksi untuk memperkuat pembuktian bahwa benar objek sengketa tersebut milik nenek Husni.

Suatu perbuatan yang disebut sebagai perilaku melawan hukum apabila perilaku itu bertentangan dengan hukum pada umumnya. Hukum yang dimaksud tidak hanya berupa ketentuan undang-undang, tetapi juga aturan-aturan hukum tidak tertulis yang hidup dalam masyarakat dan mengakibatkan timbulnya kerugian bagi orang lain. Berdasarkan ketentuan Pasal.1365 BW.yang menegaskan bahwa tiap perbuatan yang melanggar hukum dan dapat membawa kerugian pihak lain, mewajibkan orang yang menyebabkan kerugian tersebut karena perliku nya meenyebabkan harus mengganti rugi kepada orang tersebut

Ketentuan Pasal 1365 Burgerlijk Wetboek tersebut merupakan syarat yang harus dipenuhi dalam hal adanya perilaku melawan hukum yaitu:

1. Adanya suatu perbuatan

Apabila dihubungkan dengan petitum Penggugat terkait adanya rekayasa terbitnya akta jual-beli dan tidak cermatnya atau kurang kehati-hatian PPAT/Camat setempat dalam membuat akta jual-beli, maka Tergugat I dan Tergugat II dinayatakan telah melakukan perbuatan melawan hukum hal ini pula dibuktikan dengan adanya Akta Jual-beli No.914/Kec-Ckp/VII/1990 tertanggal 4 Juli 1990 yang berarti ada perbuatan jual-beli atas sebidang tanah yang menjadi objek sengketa.

2. Perilaku melawan hukum

Perilaku/Perbuatan yang mengandung kesalahan dapat dimaknai sebagai perbuatan tersebut bertentangan dengan undang-undang atau bertentangan dengan ketertiban umum, kesusilaan, atau asas kehati-hatian dan 
asas kepatuhan yang berlaku dalam kehidupan masyarakat. Berdasarkan alat bukti yang.diajukan.Penggugat seperti Surat Pemberitahuan Objek Pajak, surat Iuran Pembangunan Daerah, Surat Ketetapan Pajak Hasil Bumi Tahun 1967 atas nama Usni menunjukan bahwa sejarah tanah obyek sengketa dalam perkara ini memang benar milik Usni. Demikian juga.berdasarkan keterangan saksi-saksi yang pada pokoknya menyatakan bahwa mereka menggarap tanah tersebut atas ijin dan sepengetahuan Almarhum Hadiwinata yang merupakan ayah dari Penggugat dan anak dari Almarhum Usni. Begitupula dengan bukti surat keterangan kematian atas nama Usni bin Tasan, yang menyatakan Usni meninggal pada hari Jumat tanggal 15 Desember 1989, karena sakit.

Akta Jual-beli No.914/Kec-Ckp/VII/1990 tertanggal 4 Juli 1990 yang dibuat pada tanggal 4 Juli 1990, yang berarti pada tanggal tersebut berdasarkan surat keterangan kematian Usni saat dibuatnya akta jual-beli saat itu pihak penjual yaitu Usni telah meninggal dunia. Akta jual-beli tanah yang pada pokoknya merupakan suatu perjanjian dimana penjual berkehendak untuk menjual tanahnya dengan kesepakatan-kesepakatan tertentu dengan pembeli diantaranya sepakat mengenai obyeknya yang diperjualbelikan dan mengenai harganya.

Sebagaimana yang telah dipertimbangkan bahwa Akta Jual-beli No.914/Kec-Ckp/VII/1990 tertanggal 4 Juli 1990 dibuat setelah meninggalnya Usni dengan demikian perjanjian jual-beli yang dituangkan dalam Akta Jualbeli No.914/Kec-Ckp/VII/1990 tertanggal 4 Juli 1990 yang tertera dalam perjanjian tertulis Usni dan Arif Bambang Sutyadi sebagai pembeli adalah suatu keadaan yang tidak benar karena dengan meninggalnya Usni sebelum dibuatnya akta jual-beli tersebut berarti tidak pernah ada kesepakatan yang terjadi antara almarhum Usni dengan Arif Bambang Suytadi untuk jual-beli tanah dalam akta tersebut. Dengan demikian perbuatan Tergugat I yang memohon dibuatkan akta jual-beli ke PPAT/Camat Cikampek merupakan perbuatan yang bertentangan dengan undang-undang atau bertenangan dengan ketertiban umum, kesusilaan, karena tidaklah mungkin orang yang telah meninggal dunia dapat melakukan tindakan jual-beli. 
Pertimbangan terhadap adanya rekayasa yang dilakukan oleh TergugatII karena telah melanggar prinsip kehati-hatian dan ketidakcermatan dalam menjalankan tugasnya, karena tidak mungkin Usni yang telah meninggal dunia dapat melakukuan transaksi jual-beli sebagaimana tertuang dalam Akta Jualbeli No.914/Kec-Ckp/VII/1990 tertanggal 4 Juli 1990 dan akta tersebut dibuat oleh PPAT/Camat Cikarang, sehingga berdasarkan hal Tergugat-II bertentangan dengan prinsip kehati-hatian sebagai seorang PPAT karena membuat dan menerbitkan suatu akta jual-beli yang salah stau pihaknya telah meninggal dunia akan tetapi dapat disertakan dalam pembuatan Akta Jual-beli No.914/Kec-Ckp/VII/1990 tertanggal 4 Juli 1990.

Selain adanya perbuatan dan adanya kesalahan dalam pembuatan akta jual-beli, syarat lain agar suatu perbuatan dinyatakan sebagai perbuatan melawan hukum adalah adanya kerugian dan antara perbuatan dengan timbulnya kerugian ada hubungan sebab akibat atau kausalitas. Hubungan yang timbul yaitu adanya perbuatan Tergugat I dan Tergugat II sehingga terbit Akta Jual-beli No.914/Kec-Ckp/VII/1990 tertanggal 4 Juli 1990 telah mengakibatkan hak-hak hukum dari Usni yang saat ini diwakili oleh salah satu ahli warisnya yaitu Penggugat telah dilanggar karena Penggugat sebagai salah satu ahli waris dari Usni, yaitu kerugian yang sifatnya immateril.

Dengan demikian, maka perbuatan Tergugat-I yang telah merekayasa terbitnya Akta Jual-beli No.914/Kec-Ckp/VII/1990 tertanggal 4 Juli 1990 sebagai perbuatan melawan hukum dan Tergugat-II dalam menjalankan tugasnya sebagai PPAR/Camat Cikampek telah melanggar prinsip-prinsip kehati-hatian yaitu membuat akta jual-beli tanpa kehadiran penjual dan pembeli adalah perbuatan melawan hukum dan seharusnya pula akibat dari tindakan tersebut akta yang dibuat oleh H.M. Atori Hasanudin, BA, PPAT/Camat Cikampek mengancung cacat yuridis sehingga batal demi hukum dan memiliki kekuatan mengikat.

Berdasarkan pertimbangan-pertimbangan hal-hal yang ada di atas, hakim telah hakim tingkat pertama menolak seluruh eksepsi penggugat dan menerima permohonan penggugat yang diperkuat dengan putusan banding pada Pengadilan 
Volume 2 Nomor 2, Desember 2019

E-ISSN : 2655-7347

Tinggi Bandung. Melalui putusan ini, maka jual-beli tanah tersebut dinyatakan cacat secara hukum dan jual-beli dinyatakan batal demi hukum.

\section{B. Analisis Tanggung Jawab PPAT Dalam Hal Pembuatan Akta Jual-beli Tanpa} Sepengatahuan Ahli Waris

PPAT merupakan salah satu profesi atau pejabat umum yang telah diberi kewenangan oleh negara melalui peraturan perundang-undang yang mengatur secara khusus tentang jabatan profesi tersebut karena negara memerlukan pejabat yang secara khusus menanganai pembuatan akta di bidang pertanahan dan aktaakta lain mengenai perbuatan hukum tertentu yang menjadi kewenangannya. Perbuatan hukum tertentu meliputi membuat akta yang berkaitan dengan transaksi jual-beli, hibah, tukar menukar, pembagian dan pemisahan, pembagian dan pemisahan harta warisan, pemasukan dalam perseroan terbatas, hipotek dan credit verband. ${ }^{12}$ Keberadaan PPAT menjadi penting karena akta yang dibuat PPAT akan menjadi prasyarat mutlak untuk keperluan pendaftaran peralihan hak atas tanah pada kantor pertanahan setempat.

Melalui jual-beli terjadilah peralihan hak dan cara tersebut merupakan hal yang lazim di masyarakat modern saat ini karena dengan cara jual-beli seseorang dengan mudah mendapatkan dan memiliki apa yang diinginkan termasuk memiliki tanah. Dengan adanya peristiwa jual-beli tersebut, maka beralihlah hak kepemilikan dari hak penjual kepada pembeli dan menjadi kewenangan PPAT mengenai perjanjian yang menyangkut peralihan hak atas tanah termasuk jual-beli tanah. Oleh karena itu, pihak-pihak terkait penjual dan pembeli harus datang menghadap bersama-sama ke PPAT, untuk kemudian membuat akta jual-beli tanah. Apabila di wilayah tersebut tidak ada PPAT, maka dapat menghadap ke Camat setempat yang dalam jabatannya dan kapasitasnya selaku PPAT sementara. Selain menghadapt ke PPAT, dalam perjanjian jual-beli tanah juga harus memenuhi syarat sahnya perjanjian Pasal 1320 KUHP, yaitu adanya kesepakatan, kecakapan syarat objek tertentu dan kausa yang diperbolehkan.

12 B.F. Sihombing, Sistem Hukum PPAT Dalam Hukum Tanah Nasional Indonesia, Cetakan Kesatu, (Jakarta: Kencana, 2019), hal.26. 
Menjadi permasalahan adalah ketika ada peralihan hak atas tanah melalui jual-beli yang kemudian proses jual-beli terjadi adanya rekayasa dan pihak PPAT/Camat tidak menjalankan tugasnya dengan baik karena mengabaikan prinsip kewaspadaan, kecermatan dan ketelitian dalam menerima informasi para penghadap pada saat pembuatan akta jual-beli tanah sehingga timbul gugatan dari ahli waris karena merasa tidak pernah menjual akan tetapi dalam faktanya objek tanah sudah beralih kepemilikannya sebagaimana yang terjadi dalam perkara putusan Nomor 12/Pdt/G/2017/PN.Kwg. Seperti yang telah diuraikan di atas, A. Djumena selaku Penggugat sebagai ahli waris yang merupakan cucu dari Nenek Usni yang memiliki sebidang tanah seluas 4,995 ha (empat ribu sembilan ratus sembilan puluh lima hektar) di wilayah Dawuan Barat, Cikampek-Karawang yang telah meninggal tanggal 15 Desember 1989, namun pada tanggal 4 Juli 1990 terbit Akta Jual-beli No.914/Kec-Ckp/VII/1990 yang dibuat oleh Atori Hasanudin (Tergugat II) selaku PPAT/Camat Cikampek dan pihak pembelinya Arief Bambang Setyadi (Tergugat I).

Secara yuridis, akta jual-beli tersebut tidak memenuhi syarat sahnya perjanjian Pasal 1320 KUHP karena dalam transaksi jual-beli tersebut penuh dengan rekayasa kebohongan yang dilakukan oleh pihak yang tidak bertanggungjawab. Transaksi jual-beli tersebut jelas bertentangan dengan hukum karena tidak adanya kata sepakat dari Almarhum Usni maupun pihak ahli waris. Sepakat merupakan syarat mutlak agar suatu perjanjian itu sah. Sepakat disini merupakan adanya kehendak yang dapat diwujudkan melalui tindakan yang secara tegas menyatakan kesepakatannya. Jika demikian, maka dalam perjanjian jual beli ini jelas tidak terpenuhinya kata sepakat karena tidak ada kehendak dari pihak penjual karena Usni sendiri telah meninggal 6 bulan baru kemudian terbit akta jual beli.

Dengan demikian hal itu, akta jual-beli No.914/Kec-Ckp/VII/1990 dengan sendirinya menjadi cacat hukum karena dibuat berdasarkan informasi dan data yang tidak benar. Patut diduga ada pihak-pihak yang memalsukan data-data pemilik seperti tanda tangan misalnya untuk kepentingan transaksi jual-beli karena akta jual-beli tersebut dapat dibuat di hadapan PPAT/Camat setempat. Tindakan para tergugat jelas sebagai perbuatan melawan hukum karena menyalahi ketentuan 
perundang-undangan, ketertiban umum, kesusilaan dan asas kehati-hatian, serta asas kepatuhan yang berlaku di masyarakat.

Akibat hukum dari sebuah akta yang dibuat berdasarkan informasi kebohongan dan data yang tidak benar yang kemudian lolos dibuatkan akta di hadapan PPAT/Camat, maka jual-beli tanah tersebut dinyatakan cacat secara hukum dan jual-beli dinyatakan batal demi hukum dan tidak memiliki kekuatan hukum mengikat. Batal demi hukum ini artinya tetap melalui proses hukum dengan cara melakukan gugatan ke pengadilan menuntut pihak-pihak yang oleh undangundang dibenarkan untuk menuntut adanya upaya pembatalan terhadap akta jualbeli Akta Jual-beli No.914/Kec-Ckp/VII/1990.

Tindakan PPAT/Camat Cikampek dalam perkara ini hakim menyatakan sebagai perbuatan melawan hukum melanggar Pasal 1365 KUHPer. Seseorang telah yang melakukan tindakan melawan hukum, maka konsekuensi hukumnya diwajibkan untuk memberikan ganti kerugian, akan tetapi dalam putusan ini hakim tidak menghukum untuk bertanggungjawab meskipun hakim tetap menjatuhkan sebagai perbuatan melawan hukum terhadap PPAT/Camat H.M Atori Hasanudin dengan daerah kerja Kecamatan Cikampek, Kabupaten Karawang.

Menurut penulis dalam perkara putusan Nomor 12/Pdt/G/2017/PN.Kwg, sengketa jual-beli tanah di mana pembelinya maupun PPAT/Camat telah merekayasa terbitnya Akta Jual-beli No.914/Kec-Ckp/VII/1990 sehingga A. Djumena selaku ahli waris yang memiliki bukti tanda kematian Nenek Usni mudah untuk membuktikan atas perbuatan melawan hukum Tergugat-I maupun TergugatII di pengadilan. Namun demikian, penulis menyayangkan terhadap putusan hakim yang tidak memberikan sanksi sebagai bentuk tanggungjawab kepada pihak yang dirugikan. Dengan tidak adanya ganti rugi sebagai bentuk tanggungjawab dari amar putusan hakim bagi PPAT/Camat yang telah bertindak tidak hati-hati dan telah merugikan pihak Ahli Waris Nenek Usni, berarti telah ada pengabaian ketentuan Pasal 1365 KUHPer yang pada prinsipnya seseorang telah yang melakukan perbuatan melawan hukum, maka konsekuensi hukumnya diwajibkan untuk memberikan ganti kerugian sebagai bentuk tanggungjawabnya. Padahal secara teori, konsep tanggungjawab umum timbul karena adanya hubungan sebab 
akibat. Seseorang yang menjalankan tugas pada bidang profesi tertentu harus bisa bertanggungjawab secara profesional terhadap profesi yang disandangnya.

Dalam konteks tanggungjawab PPAT dalam hal pembuatan akta jual-beli, maka dapat melihat adanya hubungan hukum yang oleh negara melalui undangundang.telah memberi kewenangan PPAT untuk membuat akta-akta yang berkaitan dengan masalah pertanahan dengan masyarakat yang membutuhkan jasanya. Hubungan keduanya secara hukum telah diatur oleh undang-undang di mana PPAT dalam menajalankan tugasnya harus bersikap hati-hati, cermat dan tidak memihak. Begitupula masyarakat dalam setiap transaksi jual-beli tanah harus menghadap ke PPAT untuk pembuatan AJB, karena dengan akta tersebut sebagai bukti telah terjadinya perbuatan hukum mengenai jual-beli. Apabila tugas yang dijalankan sesuai dengan aturan hukum, maka dapat dikatakan tugas tersebut telah sesuai dengan tanggungjawabnya. Sebaliknya apabila tugas yang dijalankan tidak berdasar aturan hukum akan berakibat timbulnya masalah/perselisihan dikemudian hari. Sebagai konsekuensi, maka pihak yang dirugikan dapat dimintakan menuntut pertanggungjawaban baik secara hukum maupun tanggunjawab secara moral.

Tanggungjawab hukum dalam pembuatan akta, PPAT dituntut bertindak sesuai ketentuan normatif yang berlaku dan tidak boleh mengabaikan prinsipprinsip dalam pembuatan akta yaitu prinsip kehati-hatian dan kecermatan pada saat menerima informasi atau keterangan yang disampaikan penghadap dan perlu mengkonstantir terlebih dahulu sebelum dibuatkan akta. Tujuannya agar salah satu atau di antara para pihak yang lain tidak merasa dirugikan, karena jika hal ini diabaikan bisa saja di kemudian hari akan timbul gugatan terhadap akta dari pihak yang merasa dirugikan. Sedangkan tanggungjawab secara moral, dituntut agar selalu memperbaiki kinerja atas kekurangan yang ada agar lebih adil, lebih sesuai dengan martabat manusia, dan supaya orang-orang dapat merasakan kebahagiaan dari hasil output kerja yang telah dijalankan. Dengan adanya prinsip-prinsip moral inilah yang menjadi dasar norma kritis yang harus diletakkan dalam menjalankan profesi dalam keadaan yang semestinya. ${ }^{13}$ PPAT bertanggung jawab secara moral memberikan pelayanan yang baik berupa memberikan informasi yang jelas kepada

13 Khabib Lutfi, Masyarakat Indonesia dan Tanggungjawab Moralitas, (Analsis, Teori dan Perspektif Perkembangan Moralitas di Masyarakat), (Jakarta: Guepedia, 2018), hal. 71. 
penghadap terhadap jika ada kekurangan persyaratan-persyaratan dalam pembuatan akta dan tidak boleh memberikan salinan akta kepada orang lain yang tidak berkepentingan tanpa seizin pemilik kecuali undang-undang mengaturnya karena untuk proses balik nama karena jual-beli.

Berdasarkan aturan hukum yang berlaku, profesi sebagai PPAT/Camat dalam melaksanakan jabatannya membuat akta tanah dihadapkan dengan 4 (empat) macam bentuk pertanggungjawaban di antaranya yaitu tanggungjawab secara administrasi, tanggungjawab secara etik, tanggungjawab secara perdata dan tanggungjawab secara pidana. Keempat tanggungjawab tersebut dapat dikenakan bagi PPAT/Camat yang melanggar berdasarkan tingkat perbuatan yang dilanggarnya.

Dalam kode etik PPAT juga diatur urutan sanksi-sanksi yang dapat dikenakan PPAT sebagai bentuk pertanggungjawaban.dalam menjalankan tugas dan profesinya sebagai seorang PPAT. Kode Etik PPAT dalam Pasal 6 Ayat (1) secara tegas menyebutkan sanksi hukumannya yang meliputi:

1. Sanksi mendapat teguran;

2. Sanksi dengan peringatan;

3. Sanksi pemberhentian sementra atau schorsing dari kerikutsertaan menjadi anggota IPPAT;

4. Sanksi Onzetting (pemecatan) dari keanggotaan perkumpulan;

5. Pemberhentian dengan tidak hormat dari keanggotaan perkumpulan IPPAT.

Dalam pertimbangan hukum putusan Nomor 12/Pdt/G/2017/PN.Kwg, hakim menyatakan adanya rekayasa dalam terbitnya akta jual-beli, maka penulis berpendapat bahwa tindakan PPAT/Camat Cikampek telah melakukan pelanggaran berat, karenanya telah menerbitkan akta jual-beli yang cacat hukum sehingga menimbulkan perselisihan antara ahli waris yang tidak merasa menjual atau memindatahtangankan kepada pihak lain dengan tergugat-I selaku pihak yang membeli. Apabila PPAT/Camat yang bersangktuan dilaporkan untuk dimintakan pertanggungjawaban secara etik, maka berdasarkan pada Kode Etik PPAT sanksi dapat dikenakan yaitu merujuk pada Pasal 4 huruf (r) Kode Etik PPAT yang hukumannya meliputi: 
1. Ketentuan-ketentuan dalam Peraturan Jabatan PPAT dan ketentuan perundangundangan lainnya yang terkait dengan tugas pokok PPAT;

2. Isi sumpah jabatan;

3. Hal-hal yang menurut ketentuan Anggaran Dasar, Anggaran Rumah.Tangga dan/atau keputusan lain yang ditetapkan oleh organisasi IPPAT tidak boleh dilakukan oleh anggota perkumpulan IPPAT.

Melakukan rekayasa sehingga terbit akta jual-beli yang penuh dengan informasi kebohongan dalam perkara jelas telah melanggar ketentuan hukum dan juga melanggar kewajiban sebagai PPAT karena mengabaikan prinsip kehatihatian yaitu membuat akta jual-beli tanpa kehadiran pihak penjual menghadap kepadanya. Jadi apabila merujuk pada Kode Etik PPAT, maka tindakan tersebut dapat dikenakan sanksi berupa pemberhentian secara tidak hormat karena perbuatannya telah melanggar ketentuan dalam peraturan PPAT dan Kode Etik PPAT.

Berdasarkan hasil analisis di atas, maka dapat dilihat PPAT di Kecamatan Cikampek sebagai PPAT yang telah diputus melakukan perbuatan melawan hukum karena telah melanggat prinsip kehati-hatian dalam pembuatan akta jualbeli tersebut seharusnya bertanggung jawab kepada pihak yang dirugikan yaitu ahli waris Usni yaitu A.Djumena karena sesuai dengan Pasal 1365 Kitab Undangundang Hukum Perdata yang berisikan Setiap perilaku/perbuatan yang melawan hukum .yang oleh karena itu menimbulkan kerugian pada orang lain mewajibkan orang yang karena kesalahanya menyebabkan kerugian tersebut mengganti kerugian. Dalam isi pasal tersebut sangatlah jelas bahwa menyebutkan yang karena kesalahanya menyebabkan kerugian tersebut harus mengganti kerugian.

Sebagai bentuk tanggungjawab yang dapat dilakukan oleh PPAT/Camat H.M. Atori Hasanudin, BA, dalam melaksanakan jabatannya untuk memberikan pelayanan hukum selaku PPAT yang berwenang membuat akta otentik di bidang hukum tertentu termasuk akta di bidang pertanahan sesuai dengan wilayah kerjanya, maka untuk memberikan kemanan dalam pembuatan akta kepada masyarakat yang menghadap padanya harus bisa semaksimal mungkin membuat konstruksi hukum yang benar atas kasus tersebut. Konstruksi hukum yang harus dibuat dalam pengikatan jual beli seharusnya melibatkan ahli waris yang masih 
Volume 2 Nomor 2, Desember 2019 E-ISSN : 2655-7347

hidup yaitu dengan A.Djumena yang diketahui sebagai salah satu cucu dari nenek Usni sehingga klausula-klausila jual beli tersebut tidak melibatkan orang yang sudah meninggal dunia akan tetapi harus memfokuskan pada pihak ahli waris sehingga dengan turut dilibatkannya ahli waris yang masih hidup klausula dalam akta perjanjian jual beli memberikan perlindungan terhadap kedua belah pihak yaitu penjual dan pembeli.

\section{PENUTUP}

\section{A. Kesimpulan}

Pertanggungjawaban PPAT/Camat dalam menjalankan jabatannya akan selalu dihadapkan pada 4 (empat) macam bentuk pertanggungjawaban yaitu tanggungjawab secara administrasi, tanggungjawab secara etik, tanggungjawab secara perdata dan tanggungjawab secara pidana. Dalam perkara pembuatan akta yang penuh dengan kebohongan dan rekayasa pada Perkara Putusan Nomor 12/PDT.G/2017/PN.KWG, hakim hanya memutuskan perbuatan tersebut sebagai perbuatan melawan hukum Pasal 1365, akan tetapi PPAT/Camat yang bersangkutan tidak dikenakan sanksi hukum apapun sebagai bentuk pertanggungjawaban hukumnya.

\section{B. Saran}

1. Menyandang sebagai profesi PPAT hendaknya mengedanpkan sikap moral dan akhlak yang baik, serta dalam menjalankan tugasnya harus penuh dengan sikap kewaspadaan dalam menerima informasi dari pihak yang datang menghadap dan perlunya mengkonstantir terlebih dahulu sebelum dibuatkan akta agar tidak terjadi perselisihan di kemudian hari atas akta yang telah dibuatnya.

2. PPAT sebagai Pejabat Pembuat Akta Tanah dalam melaksanakan tugas yang menjadi kewenangannya harus tetap cermat dan teliti dalam membuat suatu akta, cermat dan teliti disni adalah Camat menjalankan tugasnya harus sesuai dengan peraturan-peraturan yang ada dan tidak.bertentang dengan peraturanperaturan yang ada, agar dikemudian hari tidak menimbulkan permasalahan yang dapat merugikan banyak pihak. 
Volume 2 Nomor 2, Desember 2019

E-ISSN : 2655-7347

\section{DAFTAR PUSTAKA}

\section{A. Buku}

Goenawan, Kian. Panduan Mengurus Sertifikat Tanah dan Property, Cetakan ke-1. (Yogyakarta: BestPublisher, 2009.)

Hajati, Sri. dkk, Buku Ajar Politik Hukum Pertanahan. Cetakan Pertama. (Surabaya: Airlangga University Press, 2017.)

Hernoko, Agus Yudha. Hukum Perjanjian Asas Proporsisionalitas dalam Kontrak Komersial. Edisi Pertama. Cetakan ke-4. (Jakarta: Kencana, 2014.)

Isnur, Eko Yulian. Tata Cara Mengurus Surat-Surat Rumah dan Tanah. Cetakan Ketiga. (Yogyakarta: Pustaka Yustisia, 2009.)

Mertokusumo, Sudikno. Hukum Acara Perdata Indonesia. (Yogyakarta; Liberty, 1981.)

Prodjodikoro, R. Wirjono. Perbuatan Melanggar Hukum. (Bandung: Sumur Bandung, 1976.)

Santoso, Urip. Pendaftaran dan Peralihan Hak Atas Tanah. (Jakarta: Penerbit Kencana, 2011.)

. Perolehan Hak Atas Tanah. Cetakan ke-1. (Jakarta: Kencana, 2015.)

. Pejabat Pembuat Akta Tanah. (Jakarta: Prenadamedia Group, 2016.)

Sembiring, Jimmy Joses. Panduan Mengurus Sertifikat Tanah. Cetakan Pertama. (Jakarta: Visimedia, 2010.)

Sihombing, B.F. Sistem Hukum PPAT Dalam Hukum Tanah Nasional Indonesia. Cetakan Ke-1. Jakarta: Kencana, 2019.)

\section{B. Peraturan.Perundang-Undang}

Indonesia.Undang-Undang Dasar Negara Republik Indonesia Tahun 1945.

Kitab Undang-Undang Hukum Perdata (Burgerlijk Wetboek).

Undang-Undang No.4 Tahun 1996 Tentang Hak Tanggungan Atas

Tanah Berserta Benda-benda yang berkaitan dengan Tanah. 


\section{Jurnal Hußzum Adigamẩ}

Volume 2 Nomor 2, Desember 2019

E-ISSN : 2655-7347
Jodhantara Aulliandika \& Gunawan Djajaputra TANGGUNG JAWAB PPAT DALAM HAL PEMBUATAN AKTA JUAL-BELI TANPA SEPENGETAHUAN AHLI WARIS

Peraturan Pemerintah nomor 24 Tahun 2016 tentang Perubahan Atas Peraturan Pemerintah Nomor 37 Tahun 1998 tentang Peraturan Jabatan Pembuat Akta Tanah.

Peraturan Pemerintah Nomor 24 Tahun 1997 tentang Pendaftaran Tanah serta Hak dan Kewajibannya.

\section{Kamus}

Subekti, R. dan R. Tjitrosudibio. Kamus Hukum. Jakarta: Prandja Paramita, 1980. 